\title{
Synthesis, Characterization and Antimicrobial Activity of Novel Pyrrolidine-3-carbonitrile Derivatives
}

\author{
M. F. El-Mansy ${ }^{1}$, L. S. Boulos ${ }^{1 *}$, and M. E. Mohram ${ }^{2}$ \\ ${ }^{1}$ Department of Organometallic and Organometalloid Chemistry, ${ }^{2}$ Microbial \\ Chemistry Department, National Research Centre, 33 El-Bohouth St.(former EL \\ Tahrir st.), P.O. 12622, Dokki, Giza, Egypt.
}

\begin{abstract}
$\mathbf{N}$ EWLY synthesized pyrrolidine-3-carbonitrile derivatives were evaluated as antimicrobial activity. The structures of these derivatives were derived from reactions of 1-(4-methoxyphenyl)-4-oxopyrrolidine-3-carbonitrile (1) with the stabilized phosphorus ylides, Wittig-Horner reagents, trialkylphosphites, as well as tris(dialkylamino)phosphines. The antimicrobial activity of the synthesized compounds was evaluated against Gram positive, Gram negative bacteria and fungi. The results showed comparable antibiotic activity to the reference antibiotic compound used in the study.
\end{abstract}

Keywords: Pyrrolidine, Wittig, Trialkylphosphite, Alkene, Antimicrobial activity.

\section{Introduction}

Pyrrolidines are heterocyclic compounds that exhibit wide array of pharmacological activities due to their ability to modulate different biological targets. [1] They possess antiinflammatory, [2] antitumor,[3] antihistaminic, [4] antihypertensive, [5] antimicrobial, [6] hypnotic, [7] anticonvulsant, [8] antiparkinsonian [9] activities. Among these starting materials for generating diverse pyrrolidne derivatives, pyrrolidinones[10] showed to be attractive ones as they possess both electrophilic and nucleophilic centers enabling them to react with various reagents. 4-cyano-pyrrolidin-3-ones[11,
12] are particularly interesting precursors for synthesis of pyrrolidines. Considering the fact that they have two electrophilic sites, enriches their chemical reactivity and led to generating novel compounds [11], [13-16] of promising biological activity.[16] Based on the literature survey and as a part of our growing interest in preparing new organophosphorus compounds. [17-20] In this article we studied the chemical behavior of 4-cyano-pyrrolidin-3-ones (1) towards organophosphorus reagents and evaluation the antimicrobial activity of the products (Fig. 1).<smiles>COc1ccc(N2CC(=O)C(C#N)C2)cc1</smiles>

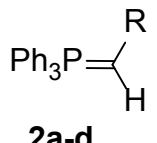
a, $R=$ COOMe
b, $R=$ COOEt
c, $\mathrm{R}=\mathrm{CN}$
$\mathrm{d}, \mathrm{R}=\mathrm{COMe}$

1<smiles>[R7]CP(=C)(C)OCC</smiles>
a, R" = OEt
$\mathrm{b}, \mathrm{R}^{\prime \prime}=\mathrm{O} i-\mathrm{Pr}$
$\mathrm{c}, \mathrm{R}^{\prime \prime}=\left[\mathrm{N}(\mathrm{Me})_{2}\right]_{3}$
$\mathrm{d}, \mathrm{R}^{\prime \prime}=[\mathrm{N}(\mathrm{Et}) 2] 3$
a, R'" = COOMe
b, $R^{\prime \prime \prime}=$ COOEt

Fig. 1. 4-cyano-pyrrolidin-3-ones (1) and organophosphorus reagents.

\footnotetext{
${ }^{*}$ Corresponding author e-mail: leilagoubran@yahoo.com DOI: $10.21608 /$ ejchem.2018.3115.1263

C2017 National Information and Documentation Centre (NIDOC)
} 


\section{Results and Discussion}

Wittig reaction $[21,22]$ of 4-cyano-pyrrolidin3 -ones (1) with stabilized ylide $2 \mathrm{a}-\mathrm{c}$ gave the corresponding unstable olefination products 6a-c. ${ }^{1} \mathrm{H}$ NMR spectra of products 6a-c showed characteristic proton around $7 \mathrm{ppm}$ indicating trisubstitiuted alkene formation. Interestingly enough, compounds 6a-c were unstable and they undergo aerobic oxidation[23] to give the corresponding $\alpha, \beta$-unsaturated compounds $7 \mathrm{a}-\mathrm{c}$ as shown in (Scheme 1).

In a similar fashion, reaction of $N$-phenyl triphenylphosphine (3) with ketone 1 gave the corresponding imine via tandem [2+2] cycloaddition-cycloreversion mechanism to provide the oxazaphosphazetidine intermediate [24] that collapses to give the imine which tautomerize to the corresponding enamine 8 (Scheme 2). The structure was assigned based on ${ }^{1} \mathrm{H}$ NMR peaks at 4.27 and $4.21 \mathrm{ppm}$ for two methylene groups in addition to the IR peak of secondary amine appeared at $3430 \mathrm{~cm}^{-1}$.
Nucleophilic attack of trialkyl phosphite/ phosphorane reagents on ketone 1 proceeds to give the corresponding enol ether compounds 9a,b and enamines 9c,d as shown in Scheme 3. These products were confirmed by spectral data, specifically; ${ }^{1} \mathrm{H}$ NMR where two methylene signals were detected in the range of 4.0 to $4.4 \mathrm{ppm}$.

A plausible mechanism of forming products $9 \mathrm{a}, \mathrm{d}$ is shown in scheme 4. The addition of trialkyl phosphite to the ketone gave intermediate 10 which undergoes nucleophilic attack on the alkyl group on the phosphorus to form compound 11. Deprotonation of compound 11 triggers the elimination of the phosphonate to proceed smoothly to $9 \mathrm{a}$. While in case of trisdiethylaminophosphorane, intramolecular reaction of compound 11 ' to kick out the alkoxy group followed by elimination to give $9 \mathrm{~d}$.

Horner-Wadsworth Emmons reaction [25] of ketone 1 with reagents $5 \mathrm{a}, \mathrm{b}$ gave the same previously isolated products $7 \mathrm{a}, \mathrm{b}$ resulted from the reaction of 1 with reagents $2 a, b$ (Scheme 5).

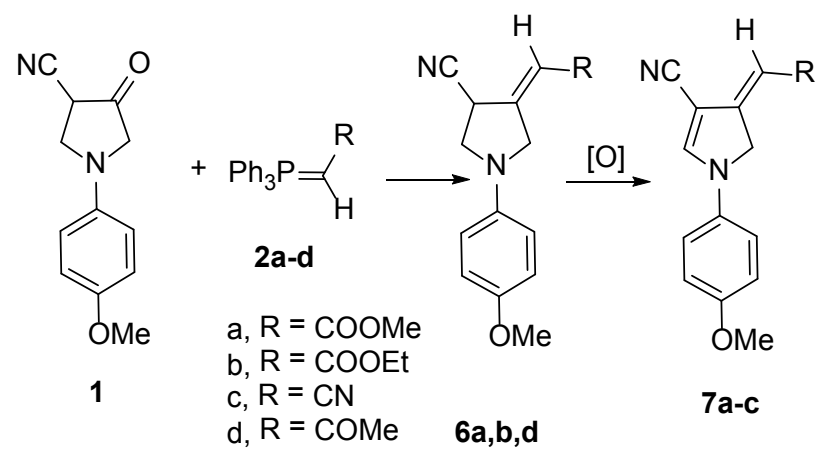

Scheme 1. Reaction of (1) with stabilized yields.

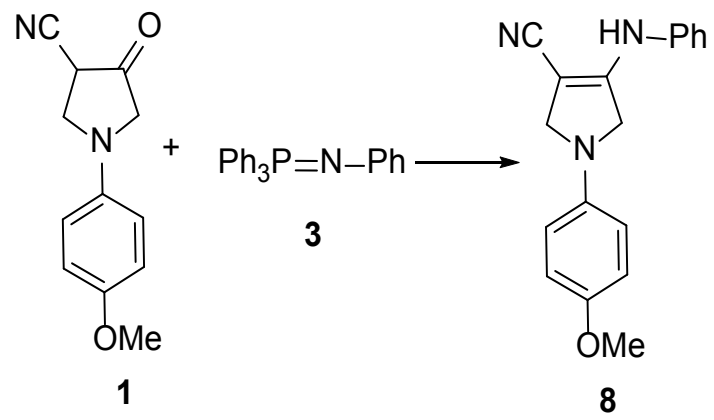

Scheme 2. Reaction of 1 with N-phenyl triphenylphosphine (3). 


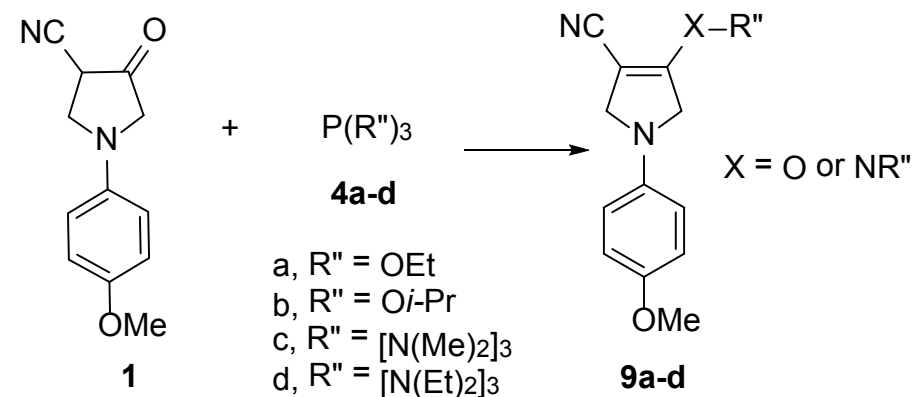

Scheme 3. Reaction of 1 with trialkyl phosphites and trisdialkylaminophosphoranes.

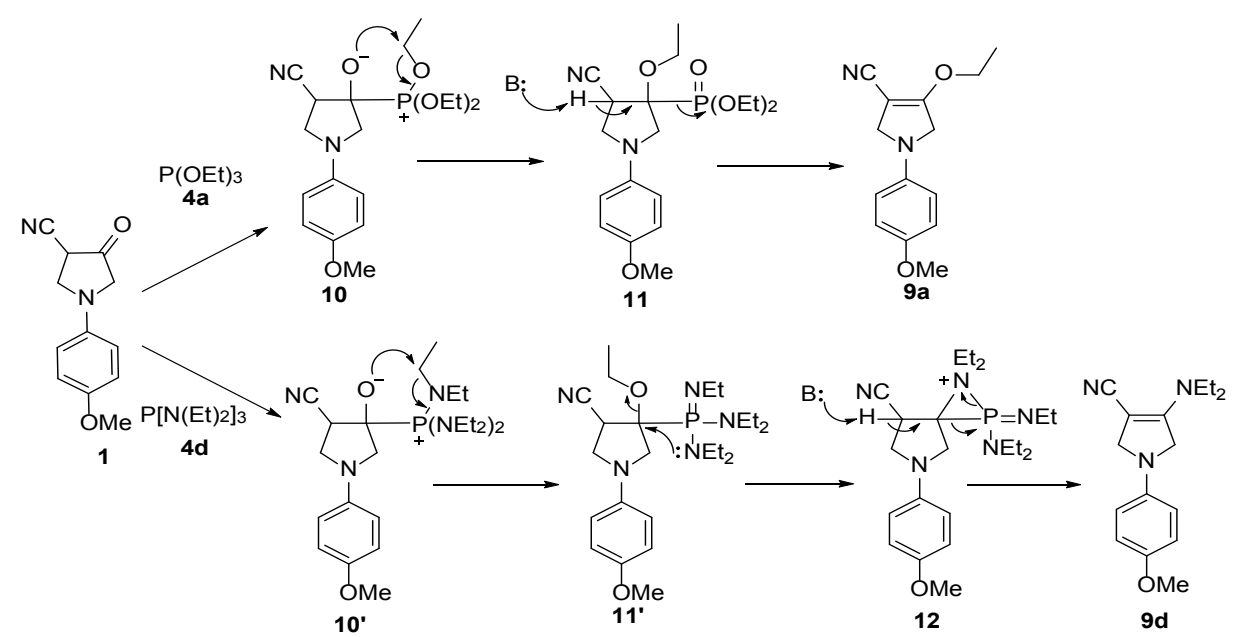

Scheme 4. Proposed mechanism for formation of 9a-d products.
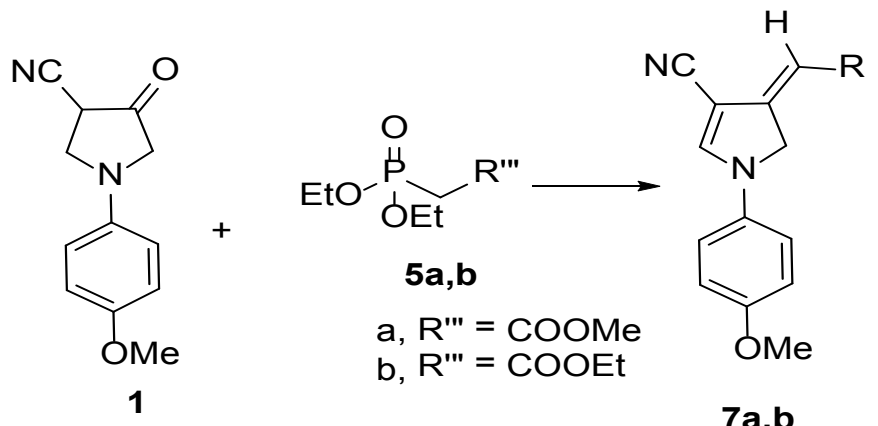

$7 a, b$

Scheme 5. Horner-Wadsworth Emmons reaction with 1.

\section{Biological evaluation}

Antimicrobial activities of seven compounds were investigated against both Gram: Bacillus subitlis, Bacillus cereus, and Stephelococcus aureus, Gram negative: Escherichia coli, Pseudomonas aeruginose, Salmonella typhimurium, and Fungus: Candida albicans. The obtained results are compared to the reference antibiotic [Nizo-arm (antifungal) and Cephradine (antimicrobial)] that were purchased from Egyptian markets.
As shown in Table 1 and Fig. 2: The compounds $6 \mathrm{~d}, 7 \mathrm{c}$ were found to be highly active compounds against Gram positive: Stephelococcus aureus (32 $\mathrm{mm}$ inhibition zone) and Gram negative: Escherichia coli (20 mm inhibition zone), respectively. These excellent results especially that of $7 \mathrm{c}$, which reaches the bioactivity of the reference antibiotic, enables us to continue the work on this antibacterial substance until reaches application stage in pharmacology studies.

Novel series of pyrrolidine-3-carbonitrile Egypt. J. Chem. 61, No. 3 (2018) 
TABLE 1. The antibacterial and antifungal activities of some synthesized compounds.

\begin{tabular}{|c|c|c|c|c|c|c|c|}
\hline \multirow[b]{2}{*}{ Compound No. } & \multicolumn{7}{|c|}{ Inhibition zone diameter $\mathrm{mm} / \mathrm{mg}$ sample } \\
\hline & \multicolumn{3}{|c|}{ Gram +ve bacteria } & \multicolumn{2}{|c|}{$\begin{array}{l}\text { Microorganism } \\
\text { Gram -ve bacteria }\end{array}$} & Sa. typhimurium & $\begin{array}{l}\text { Fungi } \\
\text { C. albicans }\end{array}$ \\
\hline 6d & 11 & 4 & 32 & 10 & 8 & 0.0 & 2 \\
\hline $7 \mathbf{a}$ & 11 & 0 & 0 & 14 & 14 & 10 & 5 \\
\hline $7 b$ & 11 & 2 & 11 & 13 & 11 & 10 & 6 \\
\hline $7 \mathrm{c}$ & 11 & 0 & 0 & 20 & 13 & 6 & 6 \\
\hline 8 & 7 & 0 & 7 & 12 & 12 & 9 & 4 \\
\hline $9 \mathbf{a}$ & 7 & 0 & 0 & 9 & 7 & 7 & 1 \\
\hline $9 \mathrm{c}$ & 10 & 3 & 0.0 & 9 & 0 & 0.0 & 4 \\
\hline $\begin{array}{c}\text { Reference } \\
\text { antibiotic. * }\end{array}$ & 30 & 40 & 30 & 20 & 50 & 40 & 44 \\
\hline
\end{tabular}

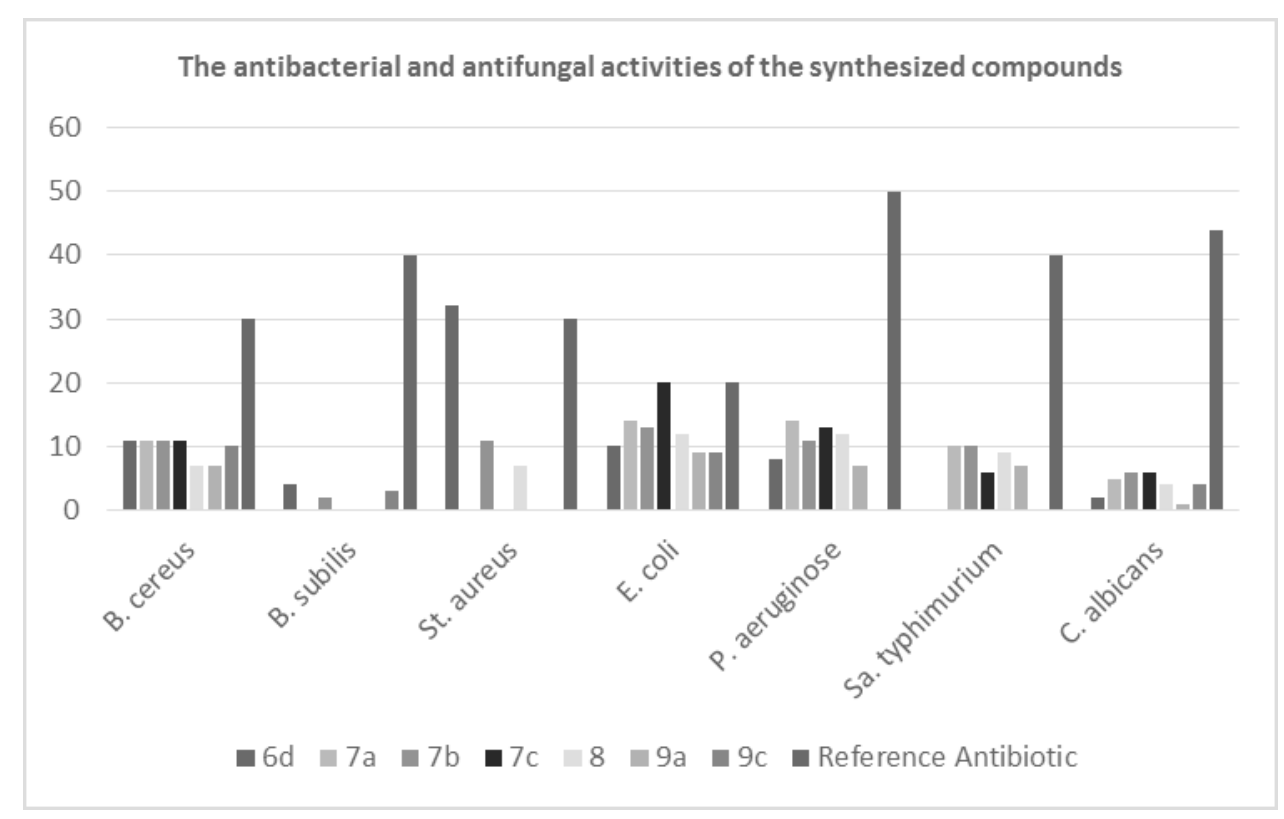

Fig. 2. The antibacterial and antifungal activities of some synthesized compounds. 
derivatives was synthesized using different organophosphorus reagents. The antimicrobial activity of these compounds was evaluated against Gram positive, Gram negative bacteria and Fungi. The results showed comparable antibiotic activity to the reference antibiotic compound.

\section{Experimental}

Melting points were determined in open glass capillaries using Electrothermal IA 9000 series digital melting point apparatus (Electrothermal, Essex, UK) and are uncorrected. The IR spectra were measured in $\mathrm{KBr}$ pellets with a PerkinElmer Infracord Spectrophotometer model 157(Grating). The ${ }^{1} \mathrm{H}$ and ${ }^{13} \mathrm{C}$ NMR spectra were recorded in $\mathrm{CDCl}_{3} /$ or DMSO- $d_{6}$ as solvent on JEOL-500 MHz Spectrometer and the chemical shifts were recorded in $\delta$ values relative to TMS. The ${ }^{31} \mathrm{P}$ NMR spectra were recorded with a Varian CFT-20 (vs. external $85 \% \mathrm{H}_{3} \mathrm{PO}_{4}$ as a standard). The mass spectra were performed at $70 \mathrm{eV}$ on a Shimada GCS-OP 1000 Ex Spectrometer provided with data system. 4-cyano-pyrrolidin3-one (1) was easily prepared according to the literature.[12]

Reactions of 1-(4-methoxyphenyl)-4-oxopyrrolidine3-carbonitrile (1) with carbmethoxymethylene triphenylphosphorane (2a).

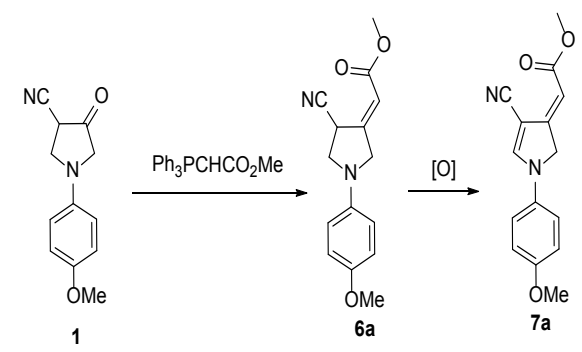

To a solution of ketone (1) (0.22 g, $1.0 \mathrm{mmol})$ in dry toluene $(30 \mathrm{~mL})$ was added ylide $2 \mathrm{a}(0.33 \mathrm{~g}$, $1.0 \mathrm{mmol})$, the mixture was refluxed. After $1 \mathrm{~h}$, the reaction was concentrated in vacuo and the residue was purified by column chromatography $\left(\mathrm{SiO}_{2}\right.$, eluting with $3-8 \%$ EtOAc in petroleum ether) to afford the unstable alkene (6a, 16\%) as a colorless solid followed by conjugated alkene (7a, 73\%) as oil.

Methyl(E)-2-(4-cyano-1-(4-methoxyphenyl) pyrrolidin-3-ylidene) acetate (6a)

m.p. $=91-93{ }^{\circ} \mathrm{C}$; IR (KBr) 2957, 2216, 1739, 1494, 1354, 1065, $699 \mathrm{~cm}^{-1}$; ${ }^{1} \mathrm{H}$ NMR $(500 \mathrm{MHz}$, $\left.\mathrm{CDCl}_{3}\right) \delta$ 6.83-6.96 (m, 3H), $6.44(\mathrm{~d}, J=7.5$ $\mathrm{Hz}, 2 \mathrm{H}), 4.28$ (s, 4H), 3.74 (s, 6H), $3.53(\mathrm{~s}, 1 \mathrm{H})$;
${ }^{13} \mathrm{C}$ NMR (125 MHz, $\left.\mathrm{CDCl}_{3}\right) \delta 168.32,156.73$, $151.43,142.59,117.89,115.67,115.51,113.47$, $113.31,112.64,58.71,56.04,51.97,42.77$; MS $(\mathrm{EI}, 70 \mathrm{eV}): \mathrm{m} / \mathrm{z}(\%)=272(100 \%)[\mathrm{M}]$.

Methyl (E)-2-(4-cyano-1-(4-methoxyphenyl)-1,2dihydro-3H-pyrrol-3-ylidene) acetate (7a)

IR (KBr) 2932, 2203, 1687, 1457, 1312, 1002, $663 \mathrm{~cm}^{-1} ;{ }^{1} \mathrm{H}$ NMR $\left(500 \mathrm{MHz}, \mathrm{CDCl}_{3}\right) \delta 7.31(\mathrm{~s}$, $1 \mathrm{H}), 7.19(\mathrm{~d}, J=7.4 \mathrm{~Hz}, 2 \mathrm{H}), 6.86-6.90(\mathrm{~m}, 3 \mathrm{H})$, 3.75 (s, 3H), 3.66 (s, 3H), 3.57 (s, 2H). ${ }^{13} \mathrm{C} \mathrm{NMR}$ $\left(125 \mathrm{MHz}, \mathrm{CDCl}_{3}\right) \delta 169.28,157.93,132.79$, $126.04,122.64,119.54,119.1,115.32,114.7$, 93.25, 60.7, 55.4, 31.1; MS (EI, $70 \mathrm{eV}): \mathrm{m} / \mathrm{z}(\%)$ $=270(47 \%)[\mathrm{M}]$.

Reactions of 1-(4-methoxyphenyl)-4-oxopyrrolidine3-carbonitrile (1) with carbethoxymethylene triphenylphosphorane (2b)

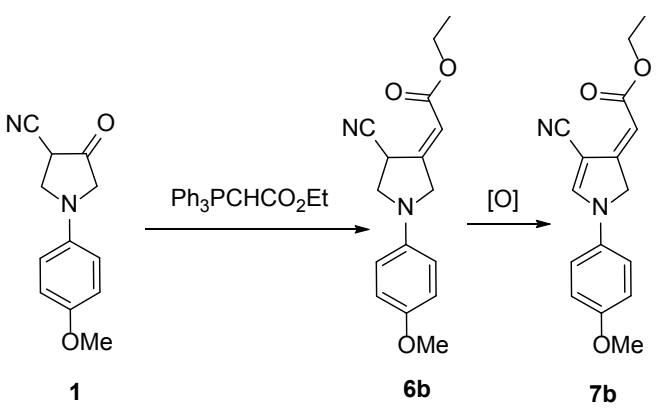

To a solution of ketone $1(0.22 \mathrm{~g}, 1.0 \mathrm{mmol})$ in dry toluene $(30 \mathrm{~mL})$ was added ylide $2 \mathrm{~b}(0.34$ $\mathrm{g}, 1.0 \mathrm{mmol})$, the mixture was refluxed. After 1 $\mathrm{h}$, the reaction was concentrated in vacuo and the residue was purified by column chromatography $\left(\mathrm{SiO}_{2}\right.$, eluting with $7-15 \%$ EtOAc in petroleum ether) to afford the unstable alkene $(6 \mathrm{~b}, 12 \%)$ as a colorless solid followed by conjugated alkene (7b, 69\%) as oil.

Ethyl (E)-2-(4-cyano-1-(4-methoxyphenyl)pyrrolidin -3-ylidene)acetate (6b)

m.p. $=73-76{ }^{\circ} \mathrm{C}$; IR (KBr) 2963, 2219, 1733, 1491, 1344, 1057, $689 \mathrm{~cm}^{-1}$; ${ }^{1} \mathrm{H}$ NMR $(500 \mathrm{MHz}$, $\left.\mathrm{CDCl}_{3}\right) \delta 6.81-6.92(\mathrm{~m}, 3 \mathrm{H}), 6.42(\mathrm{~d}, J=7.5 \mathrm{~Hz}$, $2 \mathrm{H}), 4.25$ (s, 4H), 4.30 (q, $J=7.0 \mathrm{~Hz}, 2 \mathrm{H}), 3.72$ (s, 3H), 3.52 (s, 1H), 1.35. (t, $J=7.0 \mathrm{~Hz}, 3 \mathrm{H})$; ${ }^{13} \mathrm{C}$ NMR $\left(125 \mathrm{MHz}, \mathrm{CDCl}_{3}\right) \delta 168.65,156.35$, $150.40,143.60,119.90,115.67,114.31,113.31$, $111.60,60.16,58.71,56.04,50.77,14.70$.

Ethyl(E)-2-(4-cyano-1-(4-methoxyphenyl)-1,2dihydro-3H-pyrrol-3-ylidene) acetate (7b)

IR (KBr) 2932, 2203, 1687, 1457, 1312, 1002, $663 \mathrm{~cm}^{-1} ;{ }^{1} \mathrm{H}$ NMR $\left(500 \mathrm{MHz}, \mathrm{CDCl}_{3}\right) \delta$ ppm 7.34 Egypt. J. Chem. 61, No. 3 (2018) 
(d, $J=2.3 \mathrm{~Hz}, 1 \mathrm{H}), 7.18$ - 7.28 (m, $2 \mathrm{H}), 6.89$ - 6.98 $(\mathrm{m}, 3 \mathrm{H}), 4.18$ (q, $J=6.9 \mathrm{~Hz}, 2 \mathrm{H}), 3.81(\mathrm{~s}, 3 \mathrm{H})$, $3.61(\mathrm{~s}, 2 \mathrm{H}), 1.28(\mathrm{t}, J=7.2 \mathrm{~Hz}, 3 \mathrm{H}) ;{ }^{13} \mathrm{C} \mathrm{NMR}(100$ $\left.\mathrm{MHz}, \mathrm{CDCl}_{3}\right) \delta 170.6,158.8,132.5,126.4,122.7$, $120.3,120.0,115.4,114.8,95.5,61.1,55.5,31.3$, 14.1; MS (EI, $70 \mathrm{eV}): \mathrm{m} / \mathrm{z}(\%)=28$ ¿ $(100 \%)[\mathrm{M}]$.

Reactions of 1-(4-methoxyphenyl)-4-oxopyrrolidine3-carbonitrile (1) with ylide (2c)

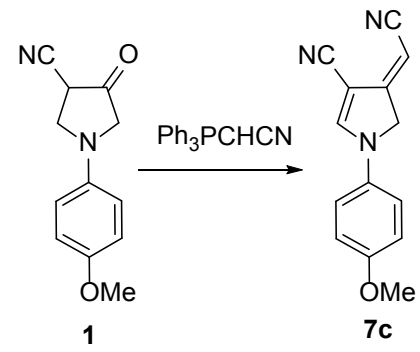

(E)-4-(cyanomethylene)-1-(4-methoxyphenyl)-4,5dihydro-1H-pyrrole-3-carbonitrile (7c)

To a solution of ketone $1(0.22 \mathrm{~g}, 1.0 \mathrm{mmol})$ in dry toluene $(10 \mathrm{~mL})$ was added ylide $2 \mathrm{c}(0.31$ g, $1.0 \mathrm{mmol})$, the mixture was refluxed. After 6 $\mathrm{h}$, the reaction was concentrated in vacuo and the residue was purified by column chromatography $\left(\mathrm{SiO}_{2}\right.$, eluting with $30 \%$ ethylacetate in petroleum ether) to afford the (7c, 67\%) as a colorless solid; m.p. $=152-155{ }^{\circ} \mathrm{C}$; IR (KBr) 3074, 2224, 2217, 1481, 1362, 1091, $714 \mathrm{~cm}^{-11}$; H NMR (500 MHz, $\left.\mathrm{CDCl}_{3}\right) \delta \mathrm{ppm} 7.39(\mathrm{~d}, J=1.2 \mathrm{~Hz}, 1 \mathrm{H}), 7.24-7.28$ (m, 2 H), 7.03 - 7.05 (m, $1 \mathrm{H}), 6.96$ - 6.99 (m, $2 \mathrm{H})$, 3.84 (s, $3 \mathrm{H}), 3.71$ (d, $J=1.2 \mathrm{~Hz}, 2 \mathrm{H}) ;{ }^{13} \mathrm{C} \mathrm{NMR}$ $\left(100 \mathrm{MHz}, \mathrm{CDCl}_{3}\right) \delta 159.2,132.0,127.4,122.9$, 120.2, 116.8, 116.5, 115.0, 114.4, 94.3, 55.6,14.8; MS (EI, $70 \mathrm{eV}): \mathrm{m} / \mathrm{z}(\%)=237(68 \%)[\mathrm{M}]$.

Reactions of 1-(4-methoxyphenyl)-4-oxopyrrolidine3-carbonitrile (1) with ylide $2 d$.

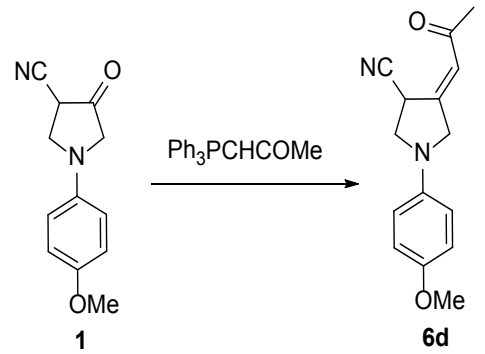

(E)-1-(4-methoxyphenyl)-4-(2-oxopropylidene) pyrrolidine-3-carbonitrile (6d)

To a solution of ketone $1(0.22 \mathrm{~g}, 1.0 \mathrm{mmol})$ in dry toluene $(30 \mathrm{~mL})$ was added ylide $2 \mathrm{~d}(0.31$ $\mathrm{g}, 1.0 \mathrm{mmol})$, the mixture was refluxed. After 6 $\mathrm{h}$, the reaction was concentrated in vacuo and the residue was purified by column chromatography $\left(\mathrm{SiO}_{2}\right.$, eluting with $15 \%$ acetone in petroleum Egypt. J. Chem. 61, No. 3 (2018) ether) to afford the (6d, 73\%) as a colorless solid; m.p. $=136-139{ }^{\circ} \mathrm{C}$; IR (KBr) 3049, 2221, 1617, 1471, 1362, 1094, $703 \mathrm{~cm}^{-1} ;{ }^{1} \mathrm{H}$ NMR $(500 \mathrm{MHz}$, $\left.\mathrm{CDCl}_{3}\right) \delta 7.27(\mathrm{~d}, J=3.3 \mathrm{~Hz}, 1 \mathrm{H}), 6.87(\mathrm{~d}, J=9.4$ $\mathrm{Hz}, 2 \mathrm{H}), 6.46(\mathrm{~d}, J=9.4 \mathrm{~Hz}, 2 \mathrm{H}), 4.83(\mathrm{~s}, 2 \mathrm{H})$, $4.82(\mathrm{~s}, 2 \mathrm{H}), 3.77(\mathrm{~s}, 3 \mathrm{H}), 3.68(\mathrm{~s}, 1 \mathrm{H}), 3.18(\mathrm{~s}$, 1H), $2.30(\mathrm{~s}, 3 \mathrm{H}) ;{ }^{13} \mathrm{C} \mathrm{NMR}\left(125 \mathrm{MHz}, \mathrm{CDCl}_{3}\right) \delta$ 199.44, 151.43, 149.94, 142.59, 124.77, 117.89, 115.67, 113.3, 58.71, 56.04, 50.77, 32.3, 27.47; MS (EI, $70 \mathrm{eV}): \mathrm{m} / \mathrm{z}(\%)=256(100 \%)[\mathrm{M}]$.

Reactions of 1-(4-methoxyphenyl)-4-oxopyrrolidine -3-carbonitrile (1) with N-Phenyl triphenylphosphorane (3). 1-(4-methoxyphenyl)-4-(phenylamino)-2,5-dihydro1H-pyrrole-3-carbonitrile (8)

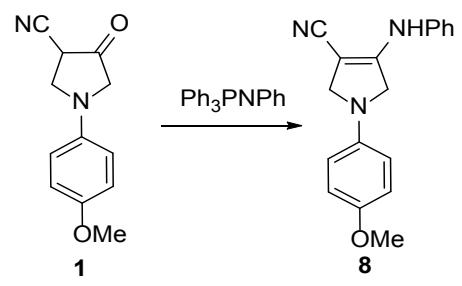

To a solution of ketone $1(0.22 \mathrm{~g}, 1.0 \mathrm{mmol})$ in dry toluene $(30 \mathrm{~mL})$ was added ylide $3(0.35$ g, $1.0 \mathrm{mmol})$, the mixture was refluxed. After 1 $\mathrm{h}$, the reaction was concentrated in vacuo and the residue was purified by column chromatography ( $\mathrm{SiO}_{2}$, eluting with 7\% EtOAc in petroleum ether) to afford the alkene $(8,81 \%)$ as a colorless solid; m.p. $=222-225^{\circ} \mathrm{C}$; IR (KBr) 3430, 2190, 1629, $1039 \mathrm{~cm}^{-1}$; ${ }^{1} \mathrm{H}$ NMR $\left(500 \mathrm{MHz}, \mathrm{CDCl}_{3}\right) \delta 7.39-$ $7.33(\mathrm{~m}, 3 \mathrm{H}), 7.19$ (d, $J=8.1 \mathrm{~Hz}, 2 \mathrm{H}), 6.96$ (d, $J$ $=9.2 \mathrm{~Hz}, 2 \mathrm{H}), 6.47(\mathrm{~d}, J=9.2 \mathrm{~Hz}, 2 \mathrm{H}), 4.27(\mathrm{~d}$, $J=5.4 \mathrm{~Hz}, 2 \mathrm{H}), 4.21$ (d, $J=5.4 \mathrm{~Hz}, 2 \mathrm{H}), 3.81$ (s, 1H), $3.74(\mathrm{~s}, 3 \mathrm{H}) ;{ }^{13} \mathrm{C} \mathrm{NMR}\left(125 \mathrm{MHz}, \mathrm{CDCl}_{3}\right) \delta$ $151.43,150.37,142.59,140.47,129.18,129.18$, $124.09,120.92,120.92,117.68,115.67,115.67$, 113.31, 113.31, 60.87, 56.04, 52.94. MS (EI, 70 $\mathrm{eV}): \mathrm{m} / \mathrm{z}(\%)=29 !(100 \%)[\mathrm{M}]$.

Reactions of 1-(4-methoxyphenyl)-4-oxopyrrolidine3-carbonitrile (1) with triethylphosphite $4 a$.

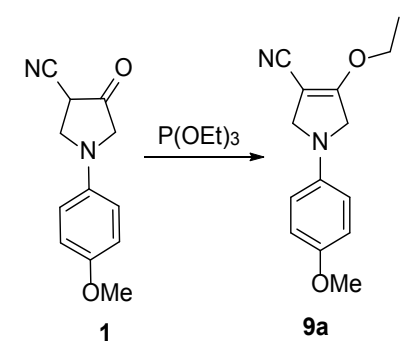

4-ethoxy-1-(4-methoxyphenyl)-2,5-dihydro- $1 \mathrm{H}$ pyrrole-3-carbonitrile (9a) 
A mixture of ketone $1(0.22 \mathrm{~g}, 1.0 \mathrm{mmol})$ and triethylphosphite (4a) (3 $\mathrm{mL})$, were heated in water bath at $70{ }^{\circ} \mathrm{C}$. After $14 \mathrm{~h}$, the excess triethylphosphite was concentrated in vacuo and the residue was purified by column chromatography $\left(\mathrm{SiO}_{2}\right.$, eluting with 30-90 \% EtOAc in petroleum ether) to afford the $(9 \mathrm{a}, 61$ $\%)$ as a colorless solid; m.p. $=161-164{ }^{\circ} \mathrm{C} ;{ }^{1} \mathrm{H}$ NMR $\left(500 \mathrm{MHz}, \mathrm{CDCl}_{3}\right) \delta 6.82(\mathrm{~d}, J=7.5, \mathrm{~Hz}$, $2 \mathrm{H}), 6.52$ (d, $J=7.5, \mathrm{~Hz}, 2 \mathrm{H}), 4.38(\mathrm{q}, J=6.0 \mathrm{~Hz}$, $2 \mathrm{H}), 4.18$ (s, 2H), 4.15 (s, 2H), 3.65 (s, 3H), 1.31 $(\mathrm{t}, J=6.0 \mathrm{~Hz}, 3 \mathrm{H}) ;{ }^{13} \mathrm{C} \mathrm{NMR}\left(125 \mathrm{MHz}, \mathrm{CDCl}_{3}\right)$ $\delta 167.2,151.3,140.8,114.8,113.0,112.2,76.0$, 67.6, 55.3, 53.0, 14.8; ppm; MS (EI, $70 \mathrm{eV}): \mathrm{m} / \mathrm{z}$ $(\%)=244(73 \%)[\mathrm{M}]$.

Reactions of 1-(4-methoxyphenyl)-4-oxopyrrolidine3-carbonitrile (1) with triisopropylphosphite (4b).

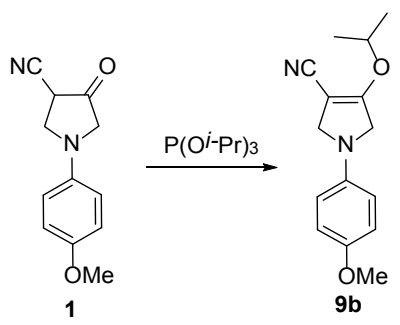

4-isopropoxy-1-(4-methoxyphenyl)-2,5-dihydro-1Hpyrrole-3-carbonitrile ( $9 b)$

A mixture of ketone $1(0.22 \mathrm{~g}, 1.0 \mathrm{mmol})$ and triisopropylphosphite $(4 \mathrm{~b})(3 \mathrm{~mL})$, were heated in water bath at $70{ }^{\circ} \mathrm{C}$. After $7 \mathrm{~h}$, the excess triethylphosphite was concentrated in vacuo and the residue was purified by column chromatography $\left(\mathrm{SiO}_{2}\right.$, eluting with $20-30 \%$ EtOAc in petroleum ether) to afford the (9b, $53 \%)$ as a colorless solid; m.p. $=183-184{ }^{\circ} \mathrm{C} ;{ }^{1} \mathrm{H}$ NMR $\left(500 \mathrm{MHz}, \mathrm{CDCl}_{3}\right) \delta$ ppm 6.93 - 7.02 (m, $2 \mathrm{H}), 6.48$ - 6.63 (m, $2 \mathrm{H})$, $5.19(\mathrm{dt}, J=12.0,6.0 \mathrm{~Hz}, 1 \mathrm{H}), 4.33(\mathrm{t}, J=4.3$ $\mathrm{Hz}, 2 \mathrm{H}), 4.18$ (t, $J=4.3 \mathrm{~Hz}, 2 \mathrm{H}), 3.87(\mathrm{~s}, 3 \mathrm{H})$, 1.54 (s, $3 \mathrm{H}), 1.52$ (s, $3 \mathrm{H}) ;{ }^{13} \mathrm{C}$ NMR (100 MHz, $\left.\mathrm{CDCl}_{3}\right) \delta 164.6,151.9,140.7,122.4,115.1,112.1$, 75.5, 74.9, 55.8, 54.9, 22.4ppm; MS (EI, $70 \mathrm{eV}$ ): $\mathrm{m} / \mathrm{z}(\%)=258(93 \%)[\mathrm{M}]$.

Reactions of 1-(4-methoxyphenyl)-4-oxopyrrolidine-3carbonitrile (1) with trisdimethylaminophosphorane (4c).

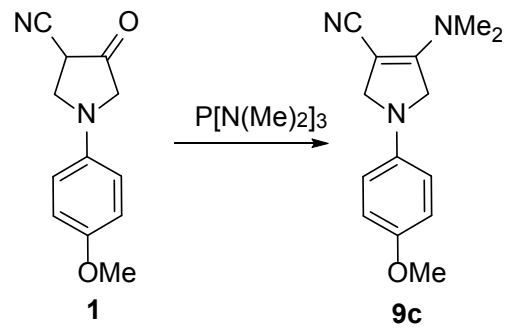

4-(dimethylamino)-1-(4-methoxyphenyl)-2,5dihydro-1H-pyrrole-3-carbonitrile (9c)

To a solution of ketone $1 \quad(0.22 \mathrm{~g}, \quad 1.0$ mmol $)$ in dry toluene $(30 \mathrm{~mL})$ was added trisdimethylaminophosphorane $4 \mathrm{c}(0.16 \mathrm{~g}, 1.0$ mmol), the mixture was refluxed. After $8 \mathrm{~h}$, the reaction was concentrated in vacuo and the residue was purified by column chromatography $\left(\mathrm{SiO}_{2}\right.$, eluting with 7\% EtOAc in petroleum ether) to afford the (9c, $48 \%)$ as a colorless solid; m.p.= 163-165 ${ }^{\circ} \mathrm{C} .{ }^{1} \mathrm{H}$ NMR $\left(500 \mathrm{MHz}, \mathrm{CDCl}_{3}\right) \delta 6.68$ $(\mathrm{d}, J=9.3 \mathrm{~Hz}, 2 \mathrm{H}), 6.38$ (d, $J=9.3 \mathrm{~Hz}, 2 \mathrm{H})$, $4.02(\mathrm{~s}, 2 \mathrm{H}), 4.01(\mathrm{~s}, 2 \mathrm{H}), 4.15(\mathrm{~s}, 1 \mathrm{H}), 3.52(\mathrm{~s}$, 3H), 2.94 (s, 6H),; $\left.{ }^{13} \mathrm{C} \mathrm{NMR} \mathrm{(125} \mathrm{MHz,} \mathrm{CDCl}_{3}\right)$ $\delta 157.4,151.3,141.2,119.9,115.0,112.5,64.0$, 55.5, 55.0, 54.8, 39.7; MS (EI, $70 \mathrm{eV}): \mathrm{m} / \mathrm{z}(\%)=$ $242(49 \%)[\mathrm{M}]^{+1}$.

Reactions of 1-(4-methoxyphenyl)-4-oxopyrrolidine-3carbonitrile (1) with trisdiethylaminophosphorane (4d).

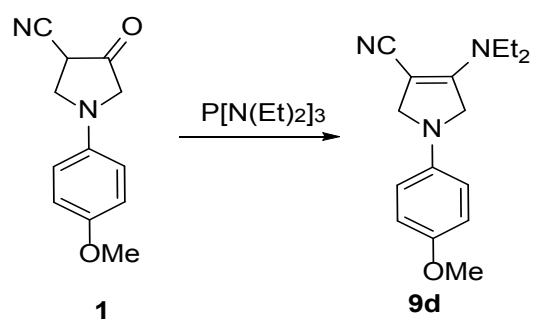

4-(diethylamino)-1-(4-methoxyphenyl)-2,5-dihydro1 H-pyrrole-3-carbonitrile (9d

To a solution of ketone $1(0.22 \mathrm{~g}, 1.0$ mmol) in dry toluene $(30 \mathrm{~mL})$ was added trisdiethylaminophosphorane $4 \mathrm{~d}(0.25 \mathrm{~g}, 1.0$ mmol), the mixture was refluxed. After $7 \mathrm{~h}$, the reaction was concentrated in vacuo and the residue was purified by column chromatography ( $\mathrm{SiO}_{2}$, eluting with $30 \%$ EtOAc in petroleum ether) to afford the (9d, $44 \%$ ) as a colorless solid; m.p. $=141-143{ }^{\circ} \mathrm{C} .{ }^{1} \mathrm{H}$ NMR $\left(500 \mathrm{MHz}, \mathrm{CDCl}_{3}\right) \delta$ $6.81(\mathrm{~d}, J=9.9,2 \mathrm{H}), 6.53(\mathrm{~d}, J=9.9,2 \mathrm{H}), 4.19$ $(\mathrm{s}, 2 \mathrm{H}), 4.08$ (s, 2H), 3.65 (s, 3H), 3.37 (q, $J=8.2$ $\mathrm{Hz}, 2 \mathrm{H}), 1.16(\mathrm{t}, J=8.2 \mathrm{~Hz}, 3 \mathrm{H}), ;{ }^{13} \mathrm{C}$ NMR $(125$ $\left.\mathrm{MHz}, \mathrm{CDCl}_{3}\right) \delta 154.9,151.1,141.0,119.3,114.7$, 112.4, 62.3, 55.3, 54.7, 54.3, 44.7, 13.9 ; MS (EI, $70 \mathrm{eV}): \mathrm{m} / \mathrm{z}(\%)=271(100 \%)[\mathrm{M}]$.

Reactions of 1-(4-methoxyphenyl)-4-oxopyrrolidine3-carbonitrile with 5 a.

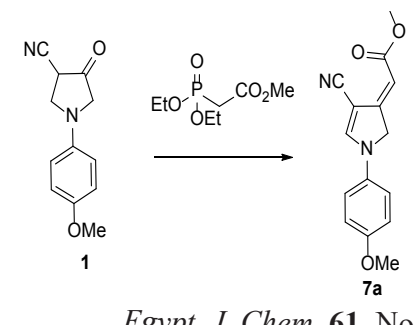

Egypt. J. Chem. 61, No. 3 (2018) 
$\operatorname{Methyl(E)-2-(4-cyano-1-(4-methoxyphenyl)-1,2-~}$ dihydro-3H-pyrrol-3-ylidene)acetate(7a)

To a solution of ketone $1(0.22 \mathrm{~g}, 1.0 \mathrm{mmol})$ in absolute ethanol $(30 \mathrm{~mL})$ was added Hornor reagent $5 \mathrm{a}(0.21 \mathrm{~g}, 1.0 \mathrm{mmol})$, followed by few drops of pipridine, the mixture was stirred. After 8 $\mathrm{h}$, the reaction was concentrated in vacuo and the residue was purified by column chromatography $\left(\mathrm{SiO}_{2}\right.$, eluting with 3-8\% EtOAc in petroleum ether) to afford (7a, 79\%) as a colorless oil.

Reactions of 1-(4-methoxyphenyl)-4-oxopyrrolidine3-carbonitrile with $5 b$.

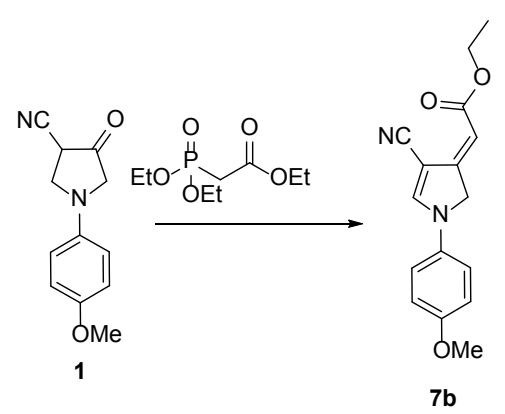

Ethyl (E)-2-(4-cyano-1-(4-methoxyphenyl)-1,2-dihydro3H-pyrrol-3-ylidene)acetate ( $7 b)$

To a solution of ketone $1(0.22 \mathrm{~g}, 1.0 \mathrm{mmol})$ in absolute ethanol $(30 \mathrm{~mL})$ was added Hornor reagent $5 \mathrm{~b}(0.22 \mathrm{~g}, 1.0 \mathrm{mmol})$, followed by few drops of pipridine, the mixture was stirred. After 7 $\mathrm{h}$, the reaction was concentrated in vacuo and the residue was purified by column chromatography ( $\mathrm{SiO} 2$, eluting with 7-15\% EtOAc in petroleum ether) to afford ( $7 \mathrm{~b}, 77 \%)$ as a colorless oil.

\section{Biological Screening}

The antibacterial and antifungal activities were carried out in the Microbial Chemistry Department, National Research Centre, using the diffusion plate method. [27-30]

\section{Procedure}

A disc of sterilized filter paper saturated with measured quantity $(25 \mu \mathrm{L})$ of the tested sample (1 $\mathrm{mg} / \mathrm{mL}$ final concentration) was placed on a plate ( $9 \mathrm{~cm}$ diameter) containing a solid bacterial medium (nutrient agar) or a fungal medium (Dox's medium) which has been seeded with the spore suspension of the test organism. After incubation at $37^{\circ} \mathrm{C}$ for $24 \mathrm{~h}$ for bacteria (in case of fungi, at $25{ }^{\circ} \mathrm{C}$ for $72 \mathrm{~h}$ ), the diameter of the clear zone of inhibition surrounding the sample was taken as a measure of the inhibitory power of the sample against the particular test organism (\% inhibition $=$ sample inhibition zone $(\mathrm{cm}) /$ plate diameter $\times$ 100). All measurements were done in chloroform Egypt. J. Chem. 61, No. 3 (2018) as a solvent except substance 8 which is dissolved in alcohol.

\section{Acknowledgment}

The authors thank the National Research Centre for the financial support (Project No: 11090112) and for the facilities provided.

\section{References}

1. Sugden J. K. and Tavakoli Saberi M., Medicinal applications of 2- and 3-substituted pyrrolidines. Pharm. Acta Helv., 51, 113 (1976).

2. Patel P. B. and Trivedi J. J., Thiazolidinones - part XIII. Synthesis of 2-aryl-3- $\beta$-aryloxyethyl-4thiazolidinones and their 1,1-dioxides. $J$. Indian Chem. Soc., 54, 765 (1977).

3. Hammam A. E.-F. G., Sharaf M. A. and El-Hafez N. A. A., Synthesis and anti-cancer activity of pyridine and thiazolopyrimidine derivatives using 1-ethylpiperidone as a synthon. Indian J. Chem. Sect. B Org. Chem. Incl. Med. Chem., 40B, 213 (2001).

4. Diurno M. V., Mazzoni O., Piscopo E., Calignano A., Giordano F. and Bolognese A., Synthesis and antihistaminic activity of some thiazolidin-4-ones. J. Med. Chem., 35, 2910 (1992).

5. Omarx M. E. and H. Eshba N., Synthesis and Biological Evaluation of New 2,3-Dihydrothiazole Derivatives for Antimicrobial, Antihypertensive, and Anticonvulsant Activities. J. Pharm. Sci., 73, 1166 (1984).

6. Singh S. P., Parmar S., Raman S. and Stenberg V. I., Chemistry and biological activity of thiazolidinones. Chem. Rev., 81, 175 (1981).

7. Chaudhary M., Parmar S. S., Chaudhary S. K., Chaturvedi A. K. and Sastry B. V. R., CNS Depressant Activity of Pyrimidylthiazolidones and their Selective Inhibition of NAD-Dependent Pyruvate Oxidation. J. Pharm. Sci., 65, 443, (1976).

8. Ragab F. A., Hussein M. M., Hanna M. M., Hassan G. S. and Kenawy S. A., Synthesis, anticonvulsant and antimicrobial activities of certain new furochromones. Egypt. J. Pharm. Sci., 34, 387 (1993).

9. Amr A. E.-G., Hegab M. I., Ibrahiem A. A. and Abdulla M. M., Synthesis and Reactions of Some Fused Oxazinone, Pyrimidinone, Thiopyrimidinone, and Triazinone Derivatives with a Thiophene Ring as Analgesic, Anticonvulsant, and Antiparkinsonian Agents. Monatshefte für Chemie / Chem. Mon., 134, 1395 (2003). 
10. Amer F. A.-K., Hammouda M., Abdel-Wahab B. F. and El-Ahl A. S.-A., Synthesis and reactions of 3-pyrrolidinones. J. Heterocycl. Chem., 45, 1549 (2008).

11. $\mathrm{Su} \mathrm{T}$. L. and Watanabe K. A., Chemistry of the pyrrolo[3,4-c]pyrido[2,3-d]pyrimidine system. Synthesis of 6,7-dihydropyrrolo[3,4-c] pyrido[2,3-d]pyrimidines, a novel ring system with potential biological interest. J. Org. Chem., 54, 220 (1989).

12. Southwick P. L., Madhav R., and Fitzgerald J. A., Compounds in the pyrrolo[3,4- $d$ ]pyrimidine series. derivatives with 6-aryl substituents. $J$. Heterocycl. Chem., 6, 507 (1969).

13. Amer F. A., Hammouda M., El-Ahl A. A. S. and Abdel-Wahab B. F., 3-Pyrrolidinones: Michael Addition and Schmidt Rearrangement Reactions. Synth. Commun., 39, 416 (2009).

14. Amer F. A., Hammouda M., El-Ahl A. S.-A. and Abdel-Wahab B. F., Synthesis of Important New Pyrrolo[3,4-c]Pyrazoles and Pyrazolyl-Pyrrolines from Heterocyclic $\beta$-Ketonitriles. J. Chinese Chem. Soc., 54, 1543 (2007).

15. Amer F. A., Hammouda M., El-Ahl A. S.-A. and Abdel-Wahab B. F., Synthesis of new pyrrolo[3,4-c]isoxazole, pyrrolo[2,3-d]-[1,2,3]triazole, triazolo[4,5-c]-pyridazine, and dipyrrolo-[3,2b:3',4'-d]pyran derivatives. Chem. Heterocycl. Compd., 43, 1559 (2007).

16. Abdalla M. M., Abdel-Wahab B. F. and Amr A.G. E., Synthesis and serotonin antagonist and antianexity activities of pyrrolidine derivatives from 4-hydrazinyl-1-p-substituted phenyl-2,5dihydro-1H-pyrrole-3-carbonitriles. Monatshefte für Chemie - Chem. Mon., 140, 129 (2009).

17. Ewies E. F., El-Shehry M. F. and Boulos L. S., Synthesis of some novel pyridazine derivatives of expected antitumor activity. Int. J. ChemTech Res., 7, 2506 (2015).

18. Ewies E. F., El-Hussieny M., El-Sayed N. F., Ali M. M. and Mahmoud A. E., Synthesis, characterization, and antitumor evaluation of 4-aminoximidofurazan derivatives. Phosphorus, Sulfur Silicon Relat. Elem., 191, 1000 (2016).

19. El-Sayed N. F., Ewies E. F., El-Hussieny M., Boulos L. S. and Shalaby E. M., Synthesis of novel pyrazole derivatives using organophosphorus, stibine, and arsine reagents and their antitumor activities. Zeitschrift für Naturforschung, B A J. Chem. Sci., 71, 765 (2016).
20. Ewies E. F., El-Sayed N. F. and Boulos L. S., The behaviour of bis(diphenylphosphino)alkanes towards different active centres. J. Chem. Res., 40, 417 (2016).

21. Wittig G. and Haag W., Über Triphenylphosphinmethylene als olefinbildende Reagenzien (II. Mitteil.1) Chem. Ber, 88, 1654 (1955).

22. Wittig G. and Schöllkopf U., Über Triphenylphosphin-methylene als olefinbildende Reagenzien (I. Mitteil.," Chem. Ber., 87, 1318 (1954).

23. Zhang J., Wang L., Liu Q., Yang Z. and Y. Huang, Synthesis of $\alpha, \beta$-unsaturated carbonyl compounds via a visible-light-promoted organocatalytic aerobic oxidation. Chem. Commun., 49, 11662 (2013).

24. Palacios F., Alonso C., Aparicio D., Rubiales G. and de los Santos, J. M. The aza-Wittig reaction: an efficient tool for the construction of carbonnitrogen double bonds. Tetrahedron, 63, 523 (2007).

25. Wadsworth W. S., Synthetic Applications of Phosphoryl-Stabilized Anions," in Organic Reactions, Hoboken, NJ, USA: John Wiley \& Sons, Inc., 1977, pp. 73-253.

26. Thomsen I., Clausen K., Scheibye S. and O. Lawesson, thiation with 2,4-bis(4methoxyphenyl)-1,3,2,4- dithiadiphosphetane 2,4-disulfide: n-methylthiopyrrolidone. Org. Synth., 62, 158 (1984).

27. Jawetz E., Melnick J. L. and E. A. Adelberg, Review of medical microbiology, Norwalk, CT Appleton \& Lange, New York, (1984).

28. D'Souza, M.-C. and Sharon M., In vitro clonal propagation of annatto (Bixa orellana L.), Vitr. Cell. Dev. Biol. Plant, 37, 168 (2001).

29. Grayer, R. J. and Harborne J. B., A survey of antifungal compounds from higher plants, 19821993," Phytochemistry, 37, 19 (1994).

30. Muanza D. N., Kim B. W., Euler K. L. and Williams L., Antibacterial and Antifungal Activities of Nine Medicinal Plants from Zaire. Int. J. Pharmacogn., 32, 337 (1994).

(Received 6/3/2018; accepted $12 / 4 / 2018$ )

Egypt. J. Chem. 61, No. 3 (2018) 


\section{تثييل و اثبات التركيب الكيميائي و دراسة النشاط الميكروبي لمشتقات جليدة لمركبات البيرولاين-ب-نيتريل

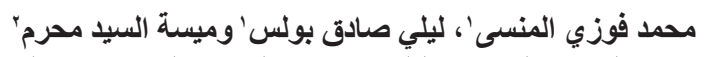

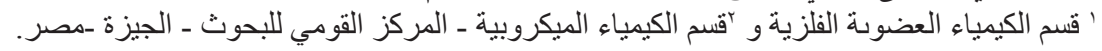

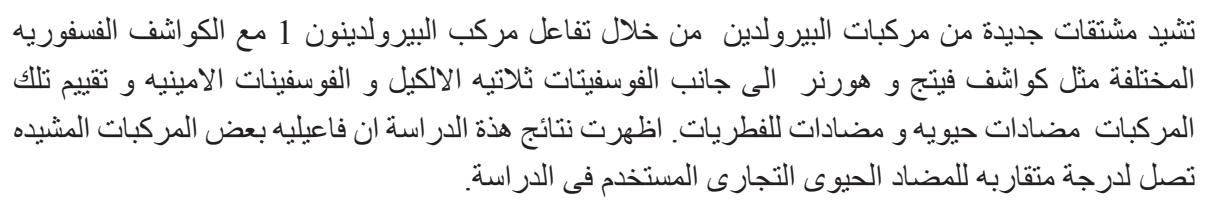

